\title{
Conceptus development after vascular occlusion of the middle uterine artery in the pig*
}

\author{
J. R. Molina, A. I. Musah, D. L. Hard and L. L. Anderson \\ Department of Animal Science, Iowa State University, Ames, Iowa 50011, U.S.A.
}

\begin{abstract}
Summary. The middle uterine artery of gilts was occluded unilaterally or bilaterally from Days 25 to 70 after mating. The results showed that vascular occlusion of one $(\mathrm{N}=7)$ or both $(\mathrm{N}=6)$ middle uterine arteries during mid-pregnancy markedly reduced, compared with sham-operated controls $(\mathrm{N}=7)$, development of the conceptuses and decreased peripheral oestrogen (oestrone + oestradiol-17 $\beta$ ) concentrations in maternal blood.
\end{abstract}

\section{Introduction}

Embryonic spacing within the pig uterus occurs coincident with increased blood supply to the gravid uterine horns (Ford \& Christenson, 1979; Hard \& Anderson, 1982). The embryos are spaced uniformly regardless of the number of them in the horn (Anderson \& Parker, 1976). Differential growth of fetuses in relation to position within the uterine horn of the pig occurs after Day 70 and when the number of fetuses exceeds 5 per horn. Similar relationships in placental weight but not in embryonic weight by Day 30 had been reported by Legault \& Leillet (1973). Positive relationships have been reported between placental blood flow and placental weight, placental weight and fetal weight, as well as placental blood flow and fetal weight during the last third of pregnancy in the pig (Wootton, McFadyen \& Cooper, 1977). In the guinea-pig ligation of a uterine artery markedly reduces maternal placental blood flow and fetal growth (Jones \& Parer, 1983). Oestrone and oestradiol-17 $\beta$ remain low during the first half of gestation in the pig, and plasma concentrations of these steroids rise about Day 70 (Robertson \& King, 1974) and remain elevated to parturition (Anderson, Adair, Stromer \& McDonald, 1983; Ford, Reynolds \& Ferrell, 1984).

The objectives of the present study were to determine the effects of unilateral or bilateral occlusion of the middle uterine artery on fetal and placental development as well as oestrogen secretion in Yorkshire gilts.

\section{Materials and Methods}

Animals and surgical procedures. Twenty nulliparous Yorkshire gilts, 6-7 months old and weighing about $130 \mathrm{~kg}$ at mating, were used. Gilts exhibiting normal oestrous cycles $(20 \pm 2$ days $)$ were mated at random by one of two fertile boars on the 1st day of the third observed oestrus (Day 0) and were assigned randomly to 1 of 3 treatment groups. Management, housing and nutritional status throughout the experiment were similar for all animals and have been described previously (Hard \& Anderson, 1979, 1982).

\footnotetext{
${ }^{*}$ Reprint requests to Dr L. L. Anderson.
} 
On Day 25 after mating, all gilts were subjected to general and surgical anaesthesia as described previously (Hard \& Anderson, 1982). The uterus and ovaries were exposed by midventral laparotomy and fetal number, as determined by gentle palpation, and number of corpora lutea were recorded. Adventitia around both middle uterine arteries in all 20 gilts was removed from a $1.5-\mathrm{cm}$ segment of the arteries 1 and $2 \mathrm{~cm}$ proximal to their first bifurcation. A nylon vascular occluder (Text-fig. 1; $10.0 \mathrm{~mm}$ length, $6.0 \mathrm{~mm}$ o.d., $4.0 \mathrm{~mm}$ i.d.) was placed around a middle uterine artery and secured within the mesometrium by silk sutures. Seven gilts had an occluder placed unilaterally around one randomly selected right or left middle uterine artery (Group U, unilateral occlusion), 6 gilts received occluders on both middle uterine arteries (Group B, bilateral occlusion), and in the remaining 7 gilts, arteries were exposed but no occluders were attached (Group C, sham-operated controls).

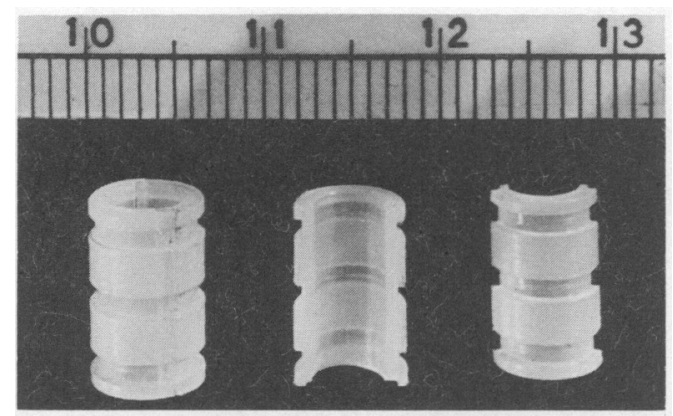

Text-fig. 1. Nylon vascular occluders $(10.0 \mathrm{~mm}$ length, $6.0 \mathrm{~mm}$ o.d., $4.0 \mathrm{~mm}$ i.d.) that were placed in the middle uterine artery before the first bifurcation and attached to the mesometrium by silk ligatures.

On Day 70 of pregnancy, gilts were again anaesthetized as described previously; the uterus and ovaries were exposed by midventral laparotomy, and pregnancy maintenance and occluder placement were verified. The umbilical cord was palpated to determine whether a fetus was living. The mesovarium, mesometrium and cervix were ligated with nylon sutures, the ovaries and uterus were removed, and blood vessels were cauterized. Ovaries, uterus and conceptuses were dissected and weighed. Fetal weight, position and crown-rump length, individual placental weight and empty uterine horn weight also were determined.

Assay procedures. Maternal blood was collected from the anterior vena cava just before surgery on Days 25 and 70 of pregnancy for the determination of peripheral serum concentrations of oestrone and oestradiol-17 $\beta$. The blood was allowed to clot at $15^{\circ} \mathrm{C}$ for $30 \mathrm{~min}$ and centrifuged at $1600 \mathrm{~g}$, and serum was stored at $-20^{\circ} \mathrm{C}$ until assayed. Radioimmunoassays for oestrone and oestradiol-17 $\beta$ were exactly as described and validated previously in this laboratory (Magness \& Ford, 1982). Within-assay variations for oestrone and oestradiol-17 $\beta$ were determined from replicates $(n=6)$ of a pool of plasma from luteal-phase sows. The resulting concentrations (mean \pm s.e.m.) and coefficients of variation were $15.6 \pm 0.4 \mathrm{pg} / \mathrm{ml}$ and $5.4 \%$ for oestrone and $13.7 \pm 0.6 \mathrm{pg} / \mathrm{ml}$ and $9 \cdot 2 \%$ for oestradiol- $17 \beta$. Between-assay coefficients of variation determined with the same plasma pool in 10 assays were $11.6 \%$ for oestrone and $8.2 \%$ for oestradiol- $17 \beta$. The sensitivity of the assay was $2.5 \mathrm{pg} / \mathrm{ml}$ for both oestrone and oestradiol- $17 \beta$.

Statistical analysis of data. Experimental units in this investigation were the individual females and their subsequent litters. Comparisons amongst attributes of fetuses produced by these females were based on analyses of litter means. The gilts were assigned to 3 treatments to form a completely randomized design. Analysis of variance indicated the error terms for testing comparisons amongst 
the 3 treatment means for each of the traits (Snedecor \& Cochran, 1980). A split-plot analysis was used to evaluate fetal weight and placental weight amongst treatments (Blair, Goodnight, Helwig \& Council, 1979).

\section{Results}

Surgical intervention at Day 25 revealed no differences $(P>0.05)$ in mean total number of live fetuses (Table 1) or total oestrogen secretion (Text-fig. 4). At Day 70, the average fetal weight, total

Table 1. Reproductive performance in pigs at Days 25 and 70 of gestation after occlusion of the middle uterine artery

\begin{tabular}{|c|c|c|c|c|c|c|}
\hline \multirow[b]{2}{*}{ Exp. group } & \multicolumn{2}{|c|}{ Total no. of live fetuses } & \multirow{2}{*}{$\begin{array}{l}\text { Day } 25 \\
\text { to Day } 70 \\
\text { fetal loss }\end{array}$} & \multicolumn{3}{|c|}{ Day $70 \dagger$} \\
\hline & Day 25 & Day 70 & & $\begin{array}{c}\text { Total ovarian } \\
\text { wt (g) }\end{array}$ & $\begin{array}{l}\text { Total no. } \\
\text { of } C L\end{array}$ & $\begin{array}{l}\text { Total uterine } \\
\text { wt (g) }\end{array}$ \\
\hline $\begin{array}{r}\text { C, sham-operated } \\
\text { controls }(N=7)\end{array}$ & $10 \cdot 7 \pm 0.6$ & $7 \cdot 2 \pm 0 \cdot 7$ & $3.5 \pm 0.9$ & $17 \cdot 3 \pm 0 \cdot 8$ & $14 \cdot 4 \pm 0.9$ & $1955 \pm 81$ \\
\hline $\begin{array}{l}\text { B, bilateral } \\
\text { occlusion }(N=6)\end{array}$ & $11 \cdot 5 \pm 1 \cdot 1$ & $5 \cdot 3 \pm 1 \cdot 6$ & $6 \cdot 2 \pm 1 \cdot 8^{*}$ & $17 \cdot 2 \pm 0 \cdot 8$ & $15 \cdot 2 \pm 0 \cdot 9$ & $1561 \pm 136^{*}$ \\
\hline $\begin{array}{l}\text { U, unilateral } \\
\text { occlusion } \\
\text { Ipsilateral } \\
\text { uterine horn } \\
(\mathrm{N}=7)\end{array}$ & $6 \cdot 3 \pm 0 \cdot 3$ & $3 \cdot 1 \pm 0 \cdot 6$ & $3 \cdot 2 \pm 0 \cdot 6$ & $8 \cdot 3 \pm 0 \cdot 7$ & $7 \cdot 4 \pm 0 \cdot 9$ & $863 \pm 51$ \\
\hline $\begin{array}{l}\text { Contralateral } \\
\text { uterine horn } \\
(\mathrm{N}=7)\end{array}$ & $6.0 \pm 0.4$ & $5.6 \pm 0.5 \ddagger$ & $0.4 \pm 0.3 \ddagger$ & $8 \cdot 9 \pm 0.8$ & $7 \cdot 9 \pm 1 \cdot 3$ & $1028 \pm 97$ \\
\hline
\end{tabular}

Values are mean \pm s.e.m.

$\uparrow$ Within all gilts, the no. of corpora lutea at Days 25 and 70 were equal.

* Significantly different from mean of sham-operated controls $(P<0.05)$.

‡ Significantly different from ipsilateral horn $(P<0 \cdot 01)$.
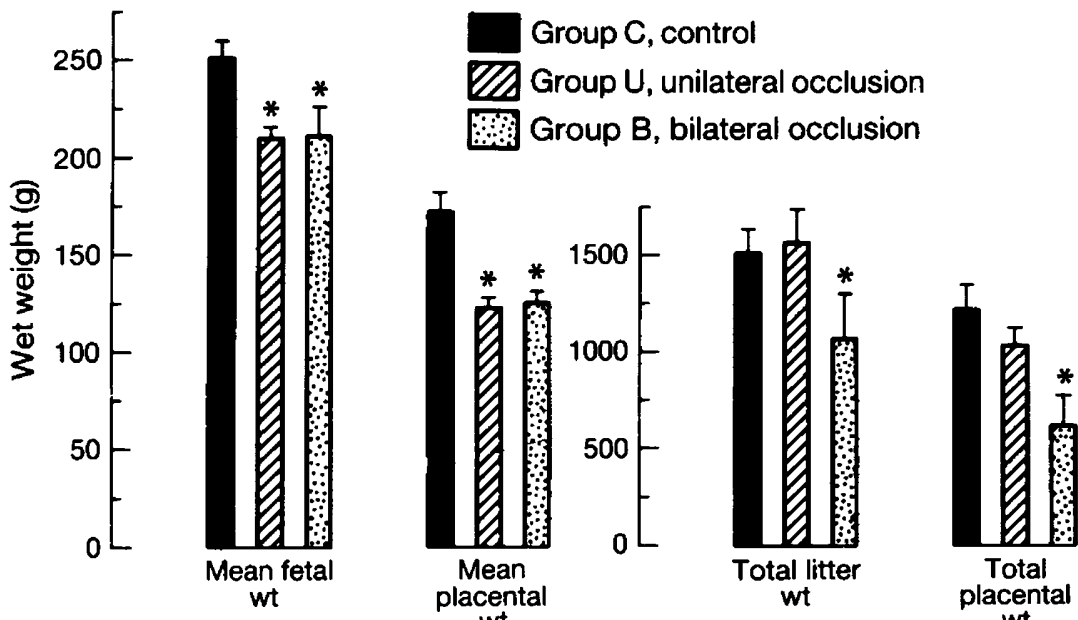

Text-fig. 2. Fetal and placental wet weights in pigs at Day 70 of gestation. Values are mean \pm s.e.m. ${ }^{*} P<0.05$ compared with values for other groups. 
litter weight, average placental weight, total placental weight and total weight of the empty uterine horn were reduced $(P<0.05)$ in gilts in Group B compared with values in Group C. The total number of viable fetuses was reduced $(P<0.01)$ from 5.9 \pm 0.3 at Day 25 to $2.8 \pm 0.4$ at Day 70 in the uterine horns with an occluder (Group B and the ipsilateral horn of Group U). In the shamoperated horns (Group $\mathrm{C}$ and the contralateral horn of Group $U$ ) the number of viable fetuses remained similar $(P>0.05)$ from Day $25(5.6 \pm 0.3)$ to Day $70(4.2 \pm 0.4)$. Furthermore, the number of fetuses was similar $(P>0.05)$ amongst uterine horns at Day 25. The average fetal weight and average placental weight were reduced $(P<0.05)$ in Group $\mathrm{U}$ gilts as compared with

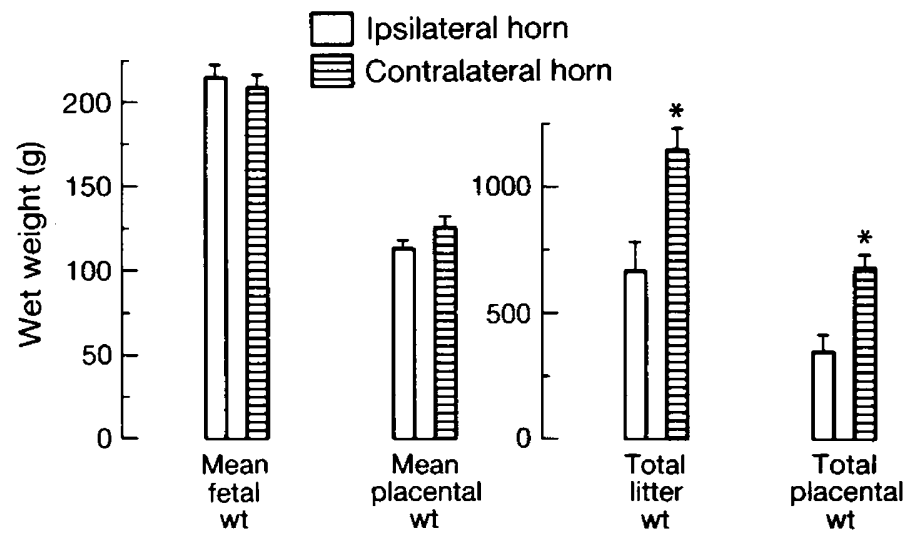

Text-fig. 3. Fetal and placental wet weights at Day 70 in the ipsilateral and contralateral uterine horn of Group $U$ gilts. Values are mean \pm s.e.m. ${ }^{*} P<0.01$ compared with value for ipsilateral horn.

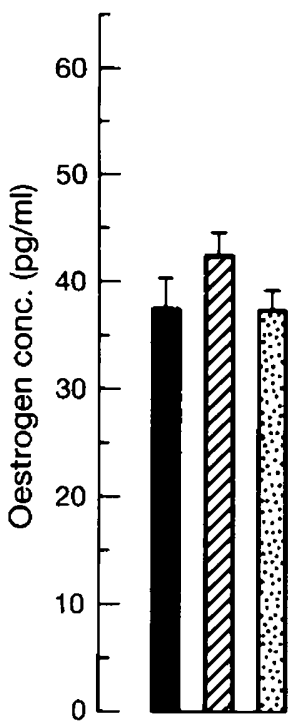

Day 25

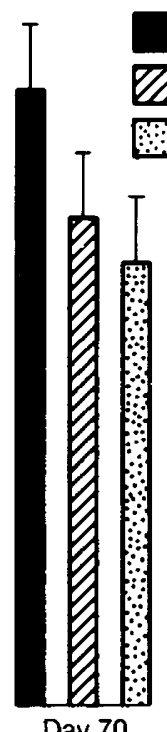

Day 70
Group C, control

Group $U$, unilateral occlusion Group B, bilateral occlusion

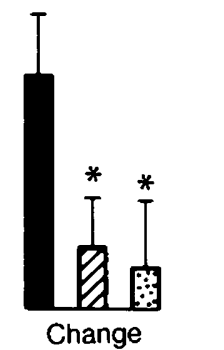

Day 25-Day 70

Text-fig. 4. Total oestrogen (oestrone + oestradiol-17ß) concentrations in peripheral blood serum at Days 25 and 70 of gestation in gilts and the change in concentrations from Days 25 to 70. Values are mean \pm s.e.m. ${ }^{*} P<0.05$ compared with Group $C$ value. 
Group C (Text-fig. 2). Within the gilts in Group $\mathrm{U}$ total fetal number, total litter weight and total placental weight on Day 70 were reduced $(P<0.01)$ in uterine horns ipsilateral as compared with horns contralateral to the occluder; however, no differences were observed in average fetal weight and average placental weight (Text-fig. 3, Table 1). Total oestrogen (oestrone plus oestradiol-17 $\beta$ ) remained similar amongst groups $(P>0.05)$ when serum concentrations were corrected for the number of conceptuses remaining viable at Day 70 . The increase in maternal peripheral total oestrogens from Day 25 to Day 70 was less $(P<0.05)$ in gilts in Groups B and U compared with values in Group C (Text-fig. 4).

\section{Discussion}

The relationship between uterine capacity and embryonic development has been examined by several methods which include superinduction and compensatory ovulation in unilaterally ovariectomized-hysterectomized gilts. A limitation of uterine space by unilateral ovariectomyhysterectomy results in placental insufficiency and is a primary cause of increased embryonic death and decreased fetal growth after Day 35 (Knight, Bazer, Thatcher, Franke \& Wallace, 1977). In intact animals most embryonic mortality occurs before Day 25 (Hanly, 1961).

In the present study, the significant reduction of average fetal weight in pigs with unilateral or bilateral occlusion of the middle uterine artery when compared with sham-operated controls may result from an inadequate availability of nutrients because of a restricted blood supply to the gravid uterus. In the unilaterally occluded gilts, the ipsilateral uterine horn had fewer fetuses $(P<0.05)$ than the contralateral uterine horn, but average fetal weight and average placental weight remained similar $(P>0.05$; Text-fig. 3). This observation may indicate that fewer fetuses in the uterine horn containing an occluder have more space for normal placental and fetal development even though blood supply had been restricted. Partial or complete obstruction of blood to the uterus causes retardation of fetal growth in the rat (Wigglesworth, 1964). In this study, the reduction in average placental weight was related to the reduction in average fetal weight and provides a useful indication of nutrient restriction for development of pig conceptuses. Therefore, in uterine horns of gilts with an occluder on a middle uterine artery and in the sham-operated uterine horns, average placental weight (range 92 to $206 \mathrm{~g})$ was correlated $(r=0.85, P<0.01)$ with average fetal weight (range 177 to $281 \mathrm{~g}$ ). Oestrone and oestradiol-17 $\beta$ are primarily of fetal-placental origin in pigs (Fèvre, Léglise \& Rombauts, 1968; Anderson et al., 1983). The peripheral blood concentrations of these steroids remain low during the first 60 days and then increase steadily to peak values just before parturition, about Day 114, whereas after hysterectomy of non-gravid gilts on Day 6, oestrone and oestradiol-17 $\beta$ remain consistently low to Day 120 (Anderson et al., 1983). In the present study, change in total oestrogen from Day 25 to Day 70 was not significant $(P>0.05)$ when serum concentrations were corrected for the number of viable conceptuses. The significant reduction in total oestrogen secretion from Day 25 to Day 70 in Groups U and B may be explained by the reduction in the total number of conceptuses necessary for oestrogen production comparable to that of sham-operated controls. The results from this investigation indicate that a vascular occluder on a middle uterine artery during midgestation limits development of the pig embryo and reduces oestrogen concentrations in maternal peripheral blood.

This study was presented in part at the 17th Meeting of the Midwestern Section of American Society of Animal Science (1984), Chicago, Illinois (Abstract 100). The study was supported in part by U.S. Department of Agriculture, Agricultural Research Service Grant 59-2191-1-2-033-0. Journal Paper No. J-11763 of the Iowa Agriculture and Home Economics Experiment Station, Ames, Iowa; Projects 2443, 2444 and 2528. 


\section{References}

Anderson, L.L. \& Parker, R.O. (1976) Distribution and development of embryos in the pig. J. Reprod. Fert. 46, 363-368.

Anderson, L.L., Adair, V., Stromer, M.H. \& McDonald, W.G. (1983) Relaxin production and release after hysterectomy in the pig. Endocrinology 113, 677-686.

Blair, W.H., Goodnight, J.H., Helwig, J.T. \& Council, K.A. (1979) SAS User's Guide, pp. 225-227. Statistical Analyses System Institute, Raleigh.

Fèvre, J., Léglise, P.C. \& Rombauts, P. (1968) Du rôle de l'hypophyse et des ovaires dans la biosynthèse des oestrogènes au cours de la gestation chez la truie. Annls Biol. anim. Biochim. Biophys. 8, 225-233.

Ford, S.P. \& Christenson, R.K. (1979) Blood flow to uteri of sows during the estrous cycle and early pregnancy: local effect of the conceptus on the uterine blood supply. Biol. Reprod. 21, 617-624.

Ford, S.P., Reynolds, L.P. \& Ferrell, C.L. (1984) Blood flow, steroid secretion and nutrient uptake of the gravid uterus during the periparturient period in sows. J. Anim. Sci. 59, 1085-1091.

Hanly, S. (1961) Prenatal mortality in farm animals. $J$. Reprod. Fert. 2, 182-187.

Hard, D.L. \& Anderson, L.L. (1979) Maternal starvation and progesterone secretion, litter size and growth in the pig. Am. J. Physiol. 237, E273-E278.

Hard, D.L. \& Anderson, L.L. (1982) Interaction of maternal blood volume and uterine blood flow with porcine fetal development. Biol. Reprod. 27, 79-90.

Jones, C.T. \& Parer, J.T. (1983) The effect of alterations in placental blood flow on the growth of and nutrient supply to the fetal guinea-pig. J. Physiol., Lond. 343, $525-537$.
Knight, J.W., Bazer, F.W., Thatcher, W.W., Franke, D.E. \& Wallace, H.D. (1977) Conceptus development in intact and unilaterally hysterectomized-ovariectomized gilts; interrelations among hormone status, placental development, fetal fluids and fetal growth. J. Anim. Sci. 44, 620-637.

Legault, C. \& Leuillet, L. (1973) Etude de quelques facteurs de variation de poids de l'embryon et du placenta chez la truie primpare au trentieme jour de la gestation. Annls Biol. anim. Biochim. Biophys. 13, 25-36.

Magness, R.R. \& Ford, S.P. (1982) Steroid concentrations in uterine lymph and uterine arterial plasma of gilts during the estrous cycle and early pregnancy. Biol. Reprod. 27, 871-877.

Robertson, H.A. \& King, G.J. (1974) Plasma concentrations of progesterone, oestrone, oestradiol-17 $\beta$ and of oestrone sulphate in the pig at implantation, during pregnancy and at parturition. J. Reprod. Fert. 40, 133-141.

Snedecor, G.W. \& Cochran, W.G. (1980) Statistical Methods, 6th edn. Iowa State University Press, Ames.

Wigglesworth, J.S. (1964) Experimental growth retardation in the foetal rat. J. Path. Bact. 88, 1-13.

Wootton, R., McFadyen, I.R. \& Cooper, J.E. (1977) Measurement of placental blood flow in the pig and its relation to placental and fetal weight. Biol. Neonate 31, 333-339. 